\title{
Practice of Reforming Entrepreneurship Education in Colleges and Universities Based on Improving College Students' Entrepreneurship Awareness
}

\author{
Baosheng Guo \\ School of history and culture, Beihua University, Jilin 132013 \\ 492171239@qq.com
}

\begin{abstract}
Keywords: College Students; Entrepreneurship Awareness; Colleges and Universities; Entrepreneurship Education
\end{abstract}

\begin{abstract}
Colleges and universities to develop the entrepreneurship education is the need of the development of the times, through the entrepreneurship education to enhance enterprise consciousness of college students is cultivating innovative talents, building an innovation oriented country needs; is to encourage and guide students to start their own businesses, to achieve high quality employment needs; is the need to achieve higher school sustainable development, improve the quality of personnel training. In this paper, by analyzing at colleges and universities to carry out entrepreneurship education present situation and the insufficiency, combined with the related survey data analysis, it is concluded that entrepreneurship education is an effective way to improve the college students' entrepreneurship awareness, and finally puts forward some effective ways, in order to realize the grand goal of "public entrepreneurship, innovation and peoples".
\end{abstract}

\section{Introduction}

In the new historical period and the background, the university student's pioneering road is not as simple as we imagine. Not only need to teach the university entrepreneurship awareness training and entrepreneurship theory, the government for entrepreneurship practice activities provide support policy, service, insurance, assistance of society, family environment, more important is the accumulation of College Students' awareness of entrepreneurship and business knowledge and literacy. Therefore, to cultivate and enhance students' awareness of entrepreneurship is not only the key to entrepreneurship education, training quality is the focus of future development and Reform in higher education. [1]

\section{The Current Situation and Problems of Entrepreneurship Education in Colleges and Universities.}

Misunderstandings for Entrepreneurship Education. Backward education concept. A lot of college leaders and teachers has yet to change the idea, think that students should learn professional knowledge and job skills. After graduation to employment, and entrepreneurship should be autonomous behavior, is not to teach, there is no need to carry out the special entrepreneurship education. [2]Narrow educational goals. The concentration of entrepreneurship education in Colleges and universities and focus on innovation ability strong, entrepreneurial aspirations of students, and ignore the guide most of the students to pay attention to and involved in the study of entrepreneurship education, the narrow scope of education hindered the more students to accept the entrepreneurial education.

Lack of Professional Teachers. The theoretical ability and practical ability of the teaching staff in Colleges and universities. The colleges and universities engaged in employment guidance and teaching personnel employment service personnel or management of students work as the main, mostly without after training and learning system, and few entrepreneurial experience, rich experience in the theory and practice ability is insufficient, unable to carry out in-depth entrepreneurship education. From outside the introduction of teachers is difficult. The University of talent management system, financial management system lacks the corresponding mechanism, is 
also limited to the report, lectures and other "shallow", it is difficult to long-term introduction entrepreneurship instructors' professional system to carry out entrepreneurship education, caused by the teachers in the surface is rich and the reality of the lack of.

Entrepreneurship Education Curriculum is not Reasonable. Course form a single, limited resources. Most colleges and universities or the "classroom teaching" as the core, not the entrepreneurial education and students practical teaching content; In addition, the current business education textbooks are not systematic, which greatly affect the development of entrepreneurship education. [3]Course setting is not strong. But the entrepreneurship education in Colleges and universities in China does not take into account these differences in different grades, different majors, different characteristics of students blindly "big pot", ignoring the students' level and subject types, in view of the lack of leading to the effectiveness is not strong.

Lack of Supporting Guidance and Growth Mechanism. Entrepreneurship support and the ability to hatch is weak. Colleges and universities in the face of growing entrepreneurial team of students, the lack of funds; The lack of school operation ability incubator, incubator construction is not perfect, which makes the subsequent support of student entrepreneurship is insufficient. [4]Policy protection is not in place. The current colleges and universities on the basis of relevant national policies allow students to quit school to start one's own business, and actively guide and help students to deal with business loans, tax preferential items, but these encourage students to leave campus entrepreneurial national policy implementation of "localization", not timely transformation or integration into the support for the entrepreneurship education of college students.

\section{Research Data and Analysis of College Students' Entrepreneurial Consciousness under the Background of Entrepreneurship Education in Colleges and Universities.}

For the better development of entrepreneurship education in Colleges and universities and college students' entrepreneurial awareness to enhance the interaction between the University Business Park in the entrepreneurial students as the main object of the actual investigation and study, has made the empirical data and analysis.

Figure 1. The Acceptance of Entrepreneurship Education in College Students' Entrepreneurship Park

\begin{tabular}{|l|c|c|c|c|c|}
\hline & & Frequency & Percent & $\begin{array}{c}\text { Valid } \\
\text { Percent }\end{array}$ & $\begin{array}{c}\text { Cumulative } \\
\text { Percent }\end{array}$ \\
\hline \multirow{4}{*}{$\begin{array}{l}\text { Respondents } \\
\text { had received } \\
\text { entrepreneurship } \\
\text { education }\end{array}$} & $\begin{array}{c}\text { Fit very } \\
\text { much }\end{array}$ & 4 & 4.7 & 4.7 & 4.7 \\
\cline { 2 - 6 } & Slightly fit & 13 & 15.1 & 15.1 & 19.8 \\
\cline { 2 - 6 } & Slightly unfit & 32 & 37.2 & 37.2 & 57.0 \\
\cline { 2 - 6 } & Unsure & 26 & 30.2 & 30.2 & 87.2 \\
\cline { 2 - 7 } & much & 11 & 12.8 & 12.8 & 100.0 \\
\hline
\end{tabular}

Data show that entrepreneurship education has not been popularized in all colleges and universities in China, only a small number of colleges and universities set up entrepreneurship education courses. 
Figure 2. The Way of Entrepreneurship Education in Domestic Universities

\begin{tabular}{|c|c|c|c|c|c|}
\hline & Frequency & Percent & $\begin{array}{c}\text { Valid } \\
\text { Percent }\end{array}$ & $\begin{array}{c}\text { Cumulative } \\
\text { Percent }\end{array}$ \\
\hline \multirow{2}{*}{$\begin{array}{c}\text { The mode of } \\
\text { entrepreneurship } \\
\text { education in } \\
\text { domestic } \\
\text { colleges and } \\
\text { Universities }\end{array}$} & $\begin{array}{c}\text { Fit very } \\
\text { much }\end{array}$ & 1 & 1.2 & 1.2 & 1.2 \\
\cline { 2 - 6 } & Slightly fit & 11 & 12.8 & 12.8 & 14.0 \\
\cline { 2 - 6 } & Slightly unfit & 39 & 45.3 & 45.3 & 59.3 \\
\cline { 2 - 6 } & Unsure & 12 & 14.0 & 14.0 & 73.3 \\
\cline { 2 - 6 } & Total very & 23 & 26.7 & 26.7 & 100.0 \\
\hline
\end{tabular}

Data illustrate the two issues: first, many entrepreneurs do not understand the entrepreneurial education, which cannot be determined from the way they can determine the quality of entrepreneurship education can be inferred; Two is in the understanding of entrepreneurship education entrepreneurs group, 2/3 of people believe that the current way of entrepreneurship education is not good.

Figure 3. School Entrepreneurship Education Teachers

\begin{tabular}{|c|c|c|c|c|c|}
\hline & Frequency & Percent & $\begin{array}{c}\text { Valid } \\
\text { Percent }\end{array}$ & $\begin{array}{c}\text { Cumulative } \\
\text { Percent }\end{array}$ \\
\hline \multirow{4}{*}{$\begin{array}{c}\text { Strong school } \\
\text { entrepreneurship } \\
\text { education } \\
\text { teachers }\end{array}$} & $\begin{array}{c}\text { Fit very } \\
\text { much }\end{array}$ & 7 & 8.1 & 8.1 & 8.1 \\
\cline { 2 - 6 } & Slightly fit & 7 & 8.1 & 8.1 & 16.3 \\
\cline { 2 - 6 } & Slightly unfit & 32 & 37.2 & 37.2 & 53.5 \\
\cline { 2 - 6 } & \begin{tabular}{c} 
Unsure \\
Unfit very \\
\cline { 2 - 6 }
\end{tabular} & 19 & 22.1 & 22.1 & 75.6 \\
\cline { 2 - 6 } & Total & 86 & 100.0 & 100.0 & 100.0 \\
\hline
\end{tabular}

Data show that entrepreneurs are not satisfied with the problem of entrepreneurship, entrepreneurship education teachers, lack of expertise, lack of experience, which is the development of entrepreneurship education must focus on improving the place.

Through the data analysis results can be known: There is a strong positive correlation between entrepreneurial awareness and entrepreneurship education, entrepreneurship education can effectively promote the improvement of College Students' entrepreneurial consciousness. Therefore, we can come to the conclusion that entrepreneurship education is an effective way to promote college students' entrepreneurship awareness promotion. [5]

The Effective Way to Strengthen the Entrepreneurship Education in Colleges and Universities to Enhance the Students' Entrepreneurial Consciousness

Change the Concept of Entrepreneurship Education, and Accurately Locate the Training Objectives of Entrepreneurship Education. Schools need to form a correct understanding. The school leadership should include entrepreneurship education in the school's regular teaching activities; Fully recognize the significance of entrepreneurship education, and strive to provide conditions for the development of entrepreneurship education, including the support of human, material and financial resources. Accurate positioning of training objectives. One is to enhance the overall quality of college students for the purpose of; Two is to cultivate the creative ability of 
college students as the main content of entrepreneurship education; Three is the personalized teaching, the students have no sense of entrepreneurship through lectures, forums and other forms to enhance the student's entrepreneurial awareness.[6]

Build Entrepreneurship Education Curriculum System, Optimize the Curriculum. Construct curriculum system. One is to construct a composite principle to follow the principle of professional talent training; content; difference principle of individual training; practice of entrepreneurship culture entrepreneurship case study principle; heuristic principle; Two is the organic integration of curriculum and content; theoretical courses and practical courses; organic integration of basic courses and professional courses; hidden curriculum and explicit curriculum organic integration. Improved teaching method. In the course of teaching, it should pay attention to guiding and developing students' ability to participate in teaching and thinking. The curriculum arrangement can take four levels of basic knowledge education, theoretical education, occupation professional knowledge education, entrepreneurship education system; Classroom teaching inside and outside of the classroom teaching, major courses and minor courses, theoretical study and practice of learning multiple Qi under the for and multi angle and comprehensive curriculum design, can effectively improve the students' awareness of entrepreneurship. [7]

Improving the Teaching Staff's Entrepreneurship Theory and Practice Level. Through the "going out" to enhance the school teachers. School should be on Teachers' professional, especially entrepreneurship courses teachers training, let teachers experience the entrepreneurial activities, improve teachers "professional combat skills; Select part outstanding person to the enterprises and institutions to exercise, to enable them to fully grasp the content of innovation and entrepreneurship education, employment, and truly become the leader in the field. Through the introduction to enrich the school entrepreneurship education teachers. To stimulate students' interest in Entrepreneurship and improve the quality of students' entrepreneurial school candidates please entrepreneurs, government officials, successful entrepreneurs, technical innovation experts, advisory division, through their lectures, and the students face to face communication to impart entrepreneurial experience and entrepreneurial training to the students and counseling. [8]

Strengthen Extracurricular Activities and Practical Teaching, Expand the Channels of Entrepreneurship Education. Colleges and universities should actively promote entrepreneurship program design contest, college students extracurricular work contest, summer student social practice activities, etc., through the holding of entrepreneurship competition, to carry out scientific and technological innovation activities. It can not only enhance students' sense of innovation and entrepreneurship, exercise and improve students' entrepreneurial ability, but also provide a platform for college students to create value for the actual productivity. Colleges and universities should be reasonably designed to practice teaching curriculum, so that the content of practical teaching is attractive, and improve students' interest in the course; In the form to very open, integrated, to enable students to grasp the initiative in the teaching practice, in purpose to clarify the practical teaching can consolidate students' theoretical knowledge and expand knowledge and developing intelligence, and students will hone and develop entrepreneurial ability. [9]

Focus on the Use and Play the Role of Entrepreneurship Education Practice Base. Pay attention to the use and play the role of College Students' pioneering park. Should be established to classroom teaching system - practice base for college students - practice system of college students' pioneering park as the core of the Trinity training system. Through the classroom teaching to enhance the students' entrepreneurial ability and theoretical knowledge accumulation, through the classroom and outside practice base to improve the ability of College Students' entrepreneurship, through the entrepreneurial park practice system to test the ability of College Students' entrepreneurship. Pay attention to the use and play the role of the school enterprise education base. The university can also use "production, learning and research, combining the opportunity, through and business cooperation in the establishment of entrepreneurship education advisory body to provide guidance for the project design and the practice, formed school set up the stage, enterprise investment, students singing" Trinity "pattern, finally realize the win-win cooperation between school and enterprises. [10] 
Nowadays is entrepreneurs realizing their ambition, achieve pioneering ideal times, entrepreneurial activity is source of power for the economic development, in line with the country's strategic direction, on the one hand can create new wealth for the society, on the one hand can be for the market to continuously inject new vitality. College students as a special group, has a unique advantage in the business, is an indispensable part of the entrepreneurial community. The suitable soil of entrepreneurship has been gradually formed, a series of encourage university students' innovative undertaking measures and policies are gradually introduced, these are college students venture created conditions, provides an opportunity. Therefore, colleges and universities have actively carried out entrepreneurship education, take effective ways and methods of cultivating the students' knowledge, skills, thinking and entrepreneurial spirit, and constantly improve the students' awareness of entrepreneurship, promote full employment of university students, bring a driving force for social adjustment of economic structure and industrial upgrade, to realize the construction of an innovative country into a powerful force.

\section{Acknowledgements}

One of the results of the stage research of Jilin Province Education Science "12th Five-Year" planning topic "entrepreneurship education in the perspective of college employment guidance curriculum reform and practice" (topic number GH150060).

\section{References}

[1] Liu Zhu. Research on the construction of College Students' entrepreneurship education and service system [J]. Liaoning Education Research, 2006(1): 95.

[2] Zhuang Meiyan. On the employment guidance curriculum reform from the perspective of College Students' Entrepreneurship Education [J]. Journal of Nanchang College of Education, 2010(6): 89 .

[3] Hou Xuwying. Reflection on College Students' Entrepreneurship Education from the perspective of Internet Entrepreneurship [J]. Chinese market, 2015(5): 163.

[4] Qiu Guikai. Thoughts on strengthening entrepreneurship education in the course of employment guidance in Colleges and Universities [J]. Science and Technology Innovation Herald, 2009(19): 256.

[5] Wang Lei. Research on the mechanism of entrepreneurship education to promote college students' Entrepreneurship[D]. Luoyang: Henan University of Science and Technology, 2014:28-29.

[6] Ou Yangyan. Research on College Students' Entrepreneurship and Entrepreneurship Education[D]. Nanchang: Jiangxi Normal University, 2008:46-47.

[7] Shu Tao,Li Junhong. The innovation and entrepreneurship education in the employment guidance education[J]. Education Research Monthly, 2009(3): 72.

[8] Yu Guanghe. Research on the cultivation and strengthening of College Students' entrepreneurial consciousness[J]. Modern Education Science, 2009(4): 153.

[9] Duan Mei. Research on the cultivation of College Students' entrepreneurial ability[D]. Baoding: Agricultural University of Hebei, 2011:28-29.

[10] Liu Yan, Wu Xiangwei, Zhang Suwei, Li Xuezheng, Gao Shuai. Research on College Students' entrepreneurial service system: a case study of College Students' entrepreneurial success in Hebei Province[J]. Modern Business, 2015(4): 275. 